\section{Iron, Folate and Vitamin B12 Status of Children and Adolescents: Single Center Study in the Aegean Region}

\author{
Çocuk ve Ergenlerin Demir, Folat ve Vitamin B12 \\ Durumları: Ege Bölgesinde Tek Merkez Çalışması
}

\section{Ayfer Çolak ${ }^{\oplus}$ Merve Zeytinli Akşit ${ }^{\oplus}$ Neşe Şimşek $\odot$ Pınar Bilgi ๑ Murat Anıl ๑}

\begin{abstract}
Objective: Although anemia is frequently seen in children, there isn't adequate number of study related with this issue. In this study, we aimed to investigate iron, folate and vitamin B12 status in children and adolescents in a single center in the Aegean region of our country.

Method: We retrospectively evaluated the children without chronic disease who were admitted to our hospital between 2008-2016 ( $n=7310)$. Ferritin, iron and iron binding capacity were measured by Olympus 2700 analyzer. Folate and vitamin B12 were measured using Immulite 2000 and Cobas E411 analyzer, respectively. MCV and hemoglobin were measured with Beckman Coulter LH750. Kruskal-Wallis and Mann-Whitney $U$ tests were used for comparison between groups.

Results: Children (2743 boys, and 4567 girls) aged between 1-18 years old were screened. The percentage of iron, folate, vitamin B12 and combined iron and vitamin B12 deficiencies were found to be $21.7 \%, 8 \%$, $16.9 \%$, and $4.7 \%$ respectively, while $18.8 \%$ of all children were in the anemic group. The incidence of combined iron and vitamin B12 in anemic group was found to be high (10.2\%), although anemic and nonanemic groups were similar with respect to vitamin B12 and folate deficiencies.

Conclusion: Iron deficiency may mask the megaloblastic anemia caused by vitamin B12 and folate deficiency. Effective preventive social nutrition programs may be useful in preventing anemia.
\end{abstract}

Keywords: Anemia, iron deficiency, folate deficiency, vitamin B12 deficiency, macrocytosis

ÖZ

Amaç: Anemi çocuklarda sık görülmekle birlikte, bu konuda yeterli çalışma bulunmamaktadır. Bu çalışmamızda, ülkemizin Ege bölgesindeki tek merkezde çocuk ve ergenlerde demir, folat ve B12 vitamini durumunu araştırmayı amaçladık.

Yöntem: 2008-2016 yılları arasında hastanemize başvuran, kronik hastalığı olmayan ( $n=7310)$ çocuklar retrospektif olarak değerlendirildi. Ferritin, demir ve demir bağlama kapasitesi Olympus 2.700 analizöründe; folat ve vitamin $B 12$ ise sırasıyla Siemens Immulite 2000 ve Roche Cobas 411 analizörü ile ölçülmüştür. MCV ve hemoglobin Beckman Coulter LH 750 hematoloji cihazında analiz edildi. Gruplar arası karşIlaştırmada, Kruskal-Wallis ve Mann-Whitney U testi kullanıldı.

Bulgular: Yaşları 1 ile 18 arasında olan çocuklar (2743 erkek ve 4567 kız) tarandı. Çocuklarda demir, folat ve B12 vitamin eksiklikleri sırasıyla \%21,7, \%8 ve \%16,9, kombine demir ve vitamin B12 eksikliği \%4,7 bulundu. Tüm çocukların \%18,8'i anemik grupta bulunuyordu. Anemik olan ve olmayan grupta vitamin $B 12$ ve folat eksikliği yüzdeleri benzer olmasına rağmen, anemik grupta kombine demir ve vitamin B12 insidansı yüksek $(\% 10,2)$ bulundu.

Sonuç: Demir eksikliği, B12 vitamini ve folat eksikliği nedeniyle oluşan megaloblastik anemiyi maskaleyebilir. Aneminin önlenmesinde, etkili koruyucu toplumsal beslenme programları yararlı olabilir.
Alındığı tarih: 04.09.2018

Kabul tarihi: 21.01.2019

Online Yayın tarihi: 06.12.2019

Merve Zeytinli Akşit Tepecik Eğitim ve Araştırma Hastanesi, Sağık Bilimleri Üniversitesi, Tıbbi Biyokimya Bölümü, İzmir - Türkiye mervezeyt@gmail.com ORCID: 0000-0003-0212-1167

A. Çolak 0000-0003-4910-0128

N. Şimşek 0000-0001-5135-8641

P. Bilgi 0000-0001-6598-0458 Tepecik Eğitim ve Araştırma Hastanesi, Sağlık Bilimleri Üniversitesi, Tıbbi Biyokimya Bölümü, Izmir, Türkiye

M. Anıl 0000-0002-2596-4944 Sağlık Bilimleri Üniversitesi, Tepecik Eğitim ve Araştırma Hastanesi, Çocuk Acil Servis, izmir, Türkiye

Anahtar kelimeler: Anemi, demir eksikliği, folat eksikliği, B12 vitamin eksikliği, makrositoz 


\section{INTRODUCTION}

One of the most important health problems in childhood is nutritional anemia which is the result of malnutrition. Nutritional anemia is an important health problem because of the negative effects on children's mental and physical development. The vast majority of nutritional anemias are iron deficiency (IDA) and vitamin B12 deficiency anemias. IDA is a result of reduction of red blood cell production due to low iron stores in the body. IDA can occur due to inadequate iron intake, decreased iron absorption, increased iron demand because of increased iron loss ${ }^{(1)}$. In many low-, and middle-income countries the prevalence of IDA among children ranges from approximately 35 to $90 \%{ }^{(2,3)}$.

Vitamin B12 is produced by microorganisms and it is only found in clams, liver, fish, crab, cheese, eggs, low-fat beef and low-fat dairy. This vitamin is involved in protein, DNA and myelin synthesis. It has a cobalt atom and also named as cobalamin. There are some biomarkers for detection of cobalamin deficiency including red blood cell mean corpuscular volume (MCV), plasma holo transcobalamin, serum cobalamin, serum methylmalonic acid and serum homocysteine. Vitamin B12 deficiency causes megaloblastic anemia characterized with formation of big and immature erythrocytes and neurological manifestations ${ }^{(4-6)}$. Vitamin B12 deficiency is more frequent in population with a poor or inadequate intake of foods containing vitamin B12, in patients with intestinal parasitosis or helicobacter pylori infections and in older adults with atrophic gastritis (due to lack of intrinsic factor production). Strict vegetarian diets may be associated with vitamin B12 deficiency ${ }^{(7)}$. In non-vegetarian populations, one of the most common causes of vitamin B12 deficiency is ImerslundGrasbeck syndrome, a specific malabsorption of vitamin B12 ${ }^{(8)}$.

Folate is a water-soluble B vitamin involved in nucleic acid, blood cells and nervous tissue synthesis. Folate is found in vegetables ${ }^{(8)}$. The lack of elements that cause nutritional anemia, may also cause gene expression abnormalities, immunological and psychological mental disorders ${ }^{(10-12)}$. The number of studies about adolescent anemia including vitamin B12 and folate deficiency are very limited in Turkey (13). In this study we aimed to investigate the iron, folate and vitamin B12 status in children and adolescents in a single center study performed in the Aegean region of Turkey.

\section{MATERIAL and METHODS}

The children admitted to our hospital between 2008-2016, aged between 1 to 18 years old without any chronic disease were investigated retrospectively. The study included 7310 children, who required analysis of vitamin B12, folate, ferritin, iron, iron binding capacity levels and complete blood counts. The study included patients who were admitted to pediatric clinics for routine control. Patients with any known chronic disease, including neutropenia, thrombocytopenia, pancytopenia, infections, continuous drug treatment, hospitalization and/or blood and blood product transfusions within one year were not included in the study. The study was approved by the hospital ethics committee.

The hospital is located in a low-income area of the city and the children referred to the hospital generally belong to low socio-economic groups. The results of 7310 children were included in the analysis. After first examination by a pediatrician, all the serum samples were drawn into gel separator tubes ie. Vacutainer SST II (Advance, Becton Dickinson) for analyses of serum vitamin B12, folate, ferritin, iron, iron binding capacity and Vacutainer K3EDTA, (Advance, Becton Dickinson) for complete blood count between 08.00 and 08.30 a.m. after a 12-hour fasting. The blood samples were allowed to clot and then centrifuged at $3000 \mathrm{rpm}$ for 10 minutes at room temperature. Measurements of serum vitamin B12, folate, ferritin, iron, iron binding capacity levels, complete blood counts were performed using simultaneously drawn blood samples. Laboratory data were collected from the hospital information system.

Ferritin levels were measured by immunoturbidimetric method; iron and iron binding capacity were measured using Olympus 2700 analyzer. Serum fola- 
te and vitamin B12 levels were measured by chemiluminescent immunoassay using an Immulite 2000 immunoassay analyzer (Siemens, Llanberis, United Kingdom) and Cobas E 411 analyzer (Roche Diagnostics, Mannheim, Germany). MCV and hemoglobin were measured with LH 750 hematology analyzer (Beckman Coulter, Miami, FL, USA).

Children were grouped into three age groups as $1-5,6-11$, and $\geq 12$ years. Vitamin B12 and folate levels below $200 \mathrm{pg} / \mathrm{ml}$ and $4 \mathrm{ng} / \mathrm{ml}$ were accepted as vitamin B12 and folate deficiency, respectively. Serum ferritin levels below $12 \mathrm{ng} / \mathrm{ml}$ were considered iron deficiency anemia ${ }^{(14)}$.

According the World Health Organization (WHO), serum vitamin B12, and folate levels of less than 203 $\mathrm{pg} / \mathrm{ml}$ and $4 \mathrm{ng} / \mathrm{ml}$, were accepted as cut-off values for vitamin B12, and folate deficiencies respectively (15). Anemia and macrocytosis according to age groups were evaluated as shown in Table $1^{(16-18)}$.

\section{Statistical methods}

Statistical analysis was performed using the Statistical Package of Social Science (SPSS), Version 15.0 (SPSS, Inc., Chicago, IL, USA). Data were expressed as median (interquartile range, 25-75 percentile). Kruskal-Wallis and Mann-Whitney $U$ tests were used for comparison between groups. Analyses were considered significant at $p<0.05$.

\section{RESULTS}

Children ( $n=7310$ ) ( 2743 boys and 4567 girls) aged between 1 to 18 years were screened. The median (25-75 percentile) serum vitamin B12 and folate concentrations were 319 (230-462) pg/ml and $8.0(5.8-11.3) \mathrm{ng} / \mathrm{ml}$ in the study group, respectively. Laboratory parameters were shown in Table 2. Of the study population, $18.8 \%$ were anemic group. $\mathrm{MCV}, \mathrm{RBC}$ and iron levels in the anemic patient group were lower than those in the non-anemic group.

Of the study population, vitamin B12 deficiency was found in $16.9 \%$ (1238/7310), folate deficiency in $8 \%$ (585/7310), iron deficiency anemia in $21.7 \%$ (1588/7310) and combined iron and vitamin B12 deficiency in $4.7 \%(342 / 7310)$ of children (Table 3$)$. The incidence of combined iron and vitamin B12 was higher in the anemic group (10.2\%), while vitamin B 12 and folate deficiencies were similar in both groups (Table 3). Iron, folate and vitamin B12 status in anemic and nonanemic patients were shown in Figure 1 . The children were grouped according to age groups as follows: $1-5$ years ( $n=1851$ : $25.3 \%)$; $6-11$ years ( $n=1610: 22.0 \%)$, and $\geq 12$ years $(n=3849$ : $52.6 \%$ ), respectively. Girls consisted $72 \%$ of the patients in the group older than 12 years was while gen-

Table 1. Hemoglobin and MCV values by age and sex.

\begin{tabular}{lccc}
\hline Age & $\begin{array}{c}\text { Hemoglobin } \\
\text { Lower limit } \\
\text { (g/dL) }\end{array}$ & $\begin{array}{c}\text { MCV } \\
\text { Lower limit } \\
\text { (fL) }\end{array}$ & $\begin{array}{c}\text { MCV } \\
\text { Upper Limit } \\
\text { (fL) }\end{array}$ \\
\hline 1 year & 11 & 71 & 89 \\
2 to 3 years & 11 & 74 & 89 \\
4 to 6 years & 11.7 & 77 & 91 \\
7 to 10 years & 12 & 78 & 91 \\
11 to 14 years & 12,3 & 80 & 94 \\
female & 12,6 & 80 & 94 \\
male & 11.5 & 81 & 96 \\
15 to 18 years & 13.7 & 81 & 96 \\
female & & & \\
male & & & \\
\hline
\end{tabular}

Table 2. Laboratory results of patients [median (25-75 percentile)].

\begin{tabular}{lccc}
\hline Variable & $\begin{array}{c}\text { All patient group } \\
(\mathbf{n = 7 3 1 0 )}\end{array}$ & $\begin{array}{c}\text { Anemic patient group } \\
(\mathbf{n = 1 3 7 6 )}\end{array}$ & $\begin{array}{c}\text { Nonanemic patient group } \\
(\mathbf{n = 5 9 3 4 )}\end{array}$ \\
\hline Hemoglobin $(\mathrm{g} / \mathrm{dl})$ & $12.5(11.7-13.4)$ & $10.5(10.0-10.8)$ & $12.7(12.0-13.5)$ \\
$\mathrm{MCV}(\mathrm{fl})$ & $81.8(77.8-85.7)$ & $75.1(69.2-79.7)$ & $82.6(79.0-86.1)$ \\
$\mathrm{RBC}(\mathrm{x} 106 / \mu \mathrm{l})$ & $4.6(4.3-4.9)$ & $4.3(4.0-4.6)$ & $4.6(4.4-4.9)$ \\
Ferritin $(\mathrm{ng} / \mathrm{ml})$ & $26.2(17.0-41.8)$ & $23.3(13.4-43.2)$ & $27.0(17.0-41.3)$ \\
Folate $(\mathrm{pg} / \mathrm{ml})$ & $8.0(5.8-11.3)$ & $10.5(7.2-15.0)$ & $7.7(5.7-10.8)$ \\
Vitamin B12 $(\mathrm{pg} / \mathrm{ml})$ & $319(230-462)$ & $362(250-527)$ & $314(228-452)$ \\
Iron $(\mathrm{U} / \mathrm{L})$ & $65(41-92)$ & $38(22-64)$ & $69(45-95)$ \\
Iron binding capacity $(\mu \mathrm{g} / \mathrm{dl})$ & $297(258-342)$ & $307(261-367)$ & $296(257-338)$ \\
& & & \\
\hline
\end{tabular}


Table 3. Characteristics of children and adolescents.

\begin{tabular}{|c|c|c|c|}
\hline & $\begin{array}{l}\text { All patient group } \\
\mathrm{N}(\%)\end{array}$ & $\begin{array}{c}\text { Anemic patient group } \\
\text { N (\%) }\end{array}$ & $\begin{array}{c}\text { Nonanemic patient group } \\
\mathbf{N}(\%)\end{array}$ \\
\hline Gender & $4567(62.5)$ & $900(65.4)$ & $3667(61.8)$ \\
\hline Boys & $2743(37.5)$ & $476(34.6)$ & $2267(38.2)$ \\
\hline Iron deficiency (Ferritin $<12 \mathrm{ng} / \mathrm{mL}$ ) & $1588(21.7)$ & $656(47.7)$ & $932(15.7)$ \\
\hline Vitamin B12 deficiency (Vitamin B12 <200 pg/mL) & $1238(16.9)$ & $229(16.6)$ & $1009(17.0)$ \\
\hline Folate deficiency (Folate $<4 \mathrm{ng} / \mathrm{dL}$ ) & $585(8)$ & $108(7.8)$ & $477(8.0)$ \\
\hline Combined iron and vitamin B12 deficiency & $342(4.7)$ & $141(10.2)$ & $201(3.4)$ \\
\hline
\end{tabular}

Table 4. Characteristics of children and adolescents by age groups.

\begin{tabular}{|c|c|c|c|c|}
\hline \multicolumn{2}{|c|}{ Age group (years) } & \multirow{2}{*}{$\begin{array}{c}\begin{array}{c}1-5 \\
\mathbf{N}(\%)\end{array} \\
898(48.5)\end{array}$} & \multirow{2}{*}{$\begin{array}{c}\begin{array}{c}6-11 \\
\mathbf{N}(\%)\end{array} \\
853(52.9)\end{array}$} & \multirow{2}{*}{$\begin{array}{c}\begin{array}{c}12-18 \\
\mathbf{N}(\%)\end{array} \\
2816(73.2)\end{array}$} \\
\hline Gender & Girls & & & \\
\hline & Boys & $953(51.5)$ & $757(47.1)$ & $1033(26.8)$ \\
\hline Total & & 1851 & 1610 & 3849 \\
\hline Anemia & & $672(36.3)$ & $101(6.3)$ & $603(15.6)$ \\
\hline Iron defi & erritin $<12 \mathrm{ng} / \mathrm{mL}$ ) & 277 (14.9) & $148(9.2)$ & $1163(30.2)$ \\
\hline Vitamin & iency (Vitamin B12 <200 pg/mL) & $152(8.2)$ & $144(8.9)$ & $942(24.5)$ \\
\hline Folate $\mathrm{d}$ & (Folate $<4 \mathrm{ng} / \mathrm{dL}$ ) & $13(0.7)$ & 31 (1.9) & $541(14.1)$ \\
\hline Combine & d vitamin B12 deficiency & $27(1.4)$ & $13(0.8)$ & $302(7.8)$ \\
\hline
\end{tabular}

Table 5. Distribution of micronutrient deficiencies by morphologic type.

\begin{tabular}{|c|c|c|c|c|c|c|c|c|}
\hline \multirow[b]{3}{*}{ Morphologic type } & \multicolumn{4}{|c|}{ All patient group } & \multicolumn{4}{|c|}{ All patient group } \\
\hline & \multicolumn{4}{|c|}{ Micronutrient deficiencies } & \multicolumn{4}{|c|}{ Micronutrient deficiencies } \\
\hline & $\begin{array}{l}\text { Iron } \\
\mathrm{N}(\%)\end{array}$ & $\begin{array}{l}\text { Folate } \\
\mathrm{N}(\%)\end{array}$ & $\begin{array}{c}\text { B12 vitamin } \\
\text { N (\%) }\end{array}$ & $\begin{array}{c}\text { Combine } \\
\mathrm{N}(\%)\end{array}$ & $\begin{array}{l}\text { Iron } \\
\text { N (\%) }\end{array}$ & $\begin{array}{l}\text { Folate } \\
\mathrm{N}(\%)\end{array}$ & $\begin{array}{c}\text { B12 vitamin } \\
\text { N (\%) }\end{array}$ & $\begin{array}{c}\text { Combine } \\
\mathbf{N}(\%)\end{array}$ \\
\hline Microcytosis & 421 (26.5) & $77(13.1)$ & 145 (11.7) & $99(28.9)$ & $379(57.7)$ & $64(59.2)$ & $113(49.3)$ & 89 (63.1) \\
\hline Normocytosis & $1167(73.4)$ & $506(86.4)$ & 1081 (87.3) & $243(71.0)$ & $277(42.3)$ & $44(40.8)$ & $108(47.2)$ & $52(36.9)$ \\
\hline Macrocytosis & 0 & $2(0.3)$ & $12(0.9)$ & 0 & 0 & 0 & $8(3.5)$ & 0 \\
\hline Total & 1588 & 585 & 1238 & 342 & 656 & 108 & 229 & 141 \\
\hline
\end{tabular}

der distribution was approximately equal in the other age groups. The highest prevalence of iron,

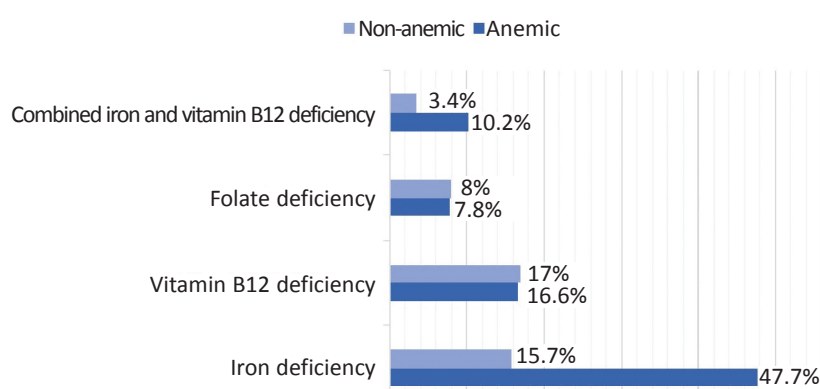

Figure 1. Iron, folate and vitamin B12 status in anemic and nonanemic patients. vitamin B12 and folate deficiency were observed among children aged 12-18 years (Table 4).

Nutrient deficiencies by morphologic type of anemia were shown in Table 5. Macrocytosis was found in 12 children with vitamin B12 deficiency.

When hemoglobin, ferritin, vitamin B12 and folate were examined by gender in all study groups, there was a difference between boys and girls in ferritin only in the group aged between 12-18 years, while other parameters were similar in all age groups (Table 6). When all values were compared between the groups, there was no difference between ferritin levels in only 1-5, 6-11 year-old girls, but there was a 
A. Çolak ve ark., Iron, Folate and Vitamin B12 Status of Children and Adolescents: Single Center Study in the Aegean Region

Table 6. Age and gender distribution of average $\mathrm{Hb}$, ferritin, vitamin $\mathrm{B} 12$, and folate levels among studied children and adolescents [median (25-75 percentile)].

\begin{tabular}{|c|c|c|c|c|c|}
\hline \multirow[b]{2}{*}{ Variables } & \multirow[b]{2}{*}{ Gender } & \multicolumn{3}{|c|}{ Age group (years) } & \multirow[b]{2}{*}{$P$ value } \\
\hline & & $1-5$ & $6-11$ & $12-18$ & \\
\hline \multirow[t]{2}{*}{ N } & Female & 896 & 853 & 2812 & \\
\hline & Male & 949 & 757 & 1032 & \\
\hline \multirow[t]{2}{*}{$\mathrm{Hb}$} & Female & $11.6(10.9-12.2)$ & $12.6(12.0-13.1)$ & $12.7(12.0-13.4)$ & $<0.001^{a, b, c}$ \\
\hline & Male & $11.5(10.9-12.1)$ & $12.6(12.0-13.3)$ & $14.2(13.3-15.1)$ & $<0.001^{a, b, c}$ \\
\hline \multirow[t]{2}{*}{ Ferritin } & Female & $27.4(18.1-42.8)$ & $29.0(20.0-40.3)$ & $21.0(13.0-33.0)$ & $0.4^{\mathrm{a}},<0.001^{\mathrm{b}, \mathrm{c}}$ \\
\hline & Male & $24.0(16.7-38.5)$ & $30.8(20.1-45.3)$ & $37.8(23.0-59.1)$ & $<0.001^{a, b, c}$ \\
\hline \multirow[t]{2}{*}{ Vitamin B12 } & Female & 417 (297-607) & 375 (274-504) & $270(205-364)$ & $<0.001^{a, b, c}$ \\
\hline & Male & $432(304-620)$ & 358 (267-495) & 255 (193-341) & $<0.001^{a, b, c}$ \\
\hline \multirow[t]{2}{*}{ Folate } & Female & $13.3(9.8-18.4)$ & $9.1(7.1-11.2)$ & $6.3(4.8-7.95)$ & $<0.001^{a, b, c}$ \\
\hline & Male & $12.9(9.5-17.4)$ & $8.8(6.7-11.1)$ & $6.2(4.7-8.1)$ & $<0.001^{a, b, c}$ \\
\hline
\end{tabular}

Mann-Whitney $U$ testi

${ }^{a} 1-5$ and $6-11,{ }^{b} 1-5$ and $12-18,{ }^{c} 6-11$ and $12-18$ years.

significant difference as for other values in all age groups $(p<0.001)$.

\section{DISCUSSION}

In underdeveloped and developing countries, anemia is common in children and elderly population. Limited studies have reported the presence of a coexistence of folate and vitamin B12 deficiency along with iron deficiency anemia ${ }^{(19)}$. Different studies with school- age children conducted in our country have showed that iron deficiency was a major problem, but there has not been sufficient information about vitamin B12 and folate deficiencies ${ }^{(13)}$.

In the current study respective percentages of children had anemia (18.8\%), iron (21.7\%), vitamin B12 (16.9\%), folate (8\%) and combined iron and vitamin B12 $(4.7 \%)$ deficiencies. Considering the age groups, the highest prevalence of anemia was observed in children between ages 12 to 18 years. In this age group the prevalence of iron, folate and vitamin B12 deficiencies were also higher than other age groups.

In Denizli province in Turkey, Balci et al. examined 1120 children between ages 12 and 16 years, detected anemia in 63 (5.6\%) of them Of the anemic children $59 \%$ had iron or combined iron, and $41 \%$ of them vitamin B12 deficiency anemia ${ }^{(20)}$. Another study found that the prevalence of iron deficiency anemia in Iranian children and adolescents was $7.9 \%$ in males and $8.5 \%$ in females ${ }^{(21)}$. Since these tests were requested from the ambulatory patients who were thought to have anemia in our hospital, in our study; the prevalence rates of iron, vitamin B12 and folate deficiencies may be higher compared to similar studies.

The pubertal period, in which fast growth and development is at a maximum is the period when most of the nutrients especially iron is needed. One of the most important reasons for increasing the frequency of anemia in this age group may be the onset of menarche in girls. In our study, approximately half of the children and adolescents between the ages of 12 and 18 years in all groups and about $2 / 3$ of this group consisted of girls. In our study, considering that girls comprised the majority of the 12-18 year-old group having higher rates of anemia, menstruation may be considered to be the most important cause of anemia, as well as inadequate and unbalanced nutrition.

In a study conducted in Mexico, among 11685 children aged 1-6 years of age, the prevalence of vitamin B12 and folate deficiencies were $7.7 \%$ and $3.2 \%$, respectively ${ }^{(9)}$.

In a study conducted with children under 5 years of age in India, the overall prevalence of cobalamin and folate deficiency was found to be $38.4 \%$ and $63.2 \%$, respectively ${ }^{(22)}$. 
In another study conducted in India with, and without breastfed breastfed children aged 6 to 30 months ( $n=2482)$ the folate levels were higher and cobalamin levels were lower in breastfed children (23). Another study found that the prevalence rates of anemia in school-age children in Mexico and Colombia were $11.6 \%$ and $4.2 \%$, respectively. The prevalence of anemia in adolescent girls in the USA was $3.6 \%{ }^{(24)}$.

In our study, the prevalence of anemia in the presence of folate deficiency was $8 \%$. One of the reasons of lower prevalence of folate deficiency anemia is that we used $4 \mathrm{ng} / \mathrm{dl}$ as its cut-off value. Also folate is ingested in the diet in many different types of food. Folate is available in a wide variety of food groups. Approximately one third of dietary folate is estimated to come from cereals and grains, another third from fruits and vegetables, and the last third from meats and fish. In Aegean region of Turkey, vegetable and fish consumption are higher than the other part of Turkey. Another reason of folate deficiency is decreased ingestion especially in infants. Impaired absorption (eg, intestinal short circuits, celiac sprue, congenital malabsorption, certain drugs such as sulfasalazine), adverse drug interactions (eg, concomitant use of folic acid antagonists such as antiepileptic medications, sulfa antibiotics, or methotrexate), increased requirements (eg, pregnancy, infancy, hyperthyroidism, chronic hemolytic disease, cancer) and increased loss (eg, hemodialysis) are other important causes of folate deficiencies ${ }^{(25)}$. We excluded the patients with chronic disease and the patients $<1$ year of age. These conditions could be related in low prevalance of folate deficiency anemia.

In megaloblastic anemia due to vitamin B12 deficiency, thrombocytopenia and leukopenia could be seen and also MCV value could be higher than normal.

Macrocytosis is one of the earliest indicators that can alert clinicians for the diagnosis of megaloblastic anemia. However, clinicians should be aware of certain coexisting conditions that may mask the macrocytosis seen in megaloblastic anemia such as thalassemia, iron deficiency and chronic illness. Under these circumstances, patients may present with normocytic or even microcytic anemia instead of typical megaloblastic anemia. In the diagnosis of megaloblastic anemia, MCV value should not be used alone (26), because iron deficiency may mask macrocytosis. Coexistence of vitamin B12 and iron deficiency anemia with either normal or low MCV levels can lead to misdiagnosis ${ }^{(27,28)}$.

One of the most important findings of present study was that only $3.5 \%$ of anemic children with vitamin B12 deficiency have macrocytosis. Megaloblastic anemia due to deficiency of vitamin B12 is also present when there is no macrocytosis or when vitamin B12 is within normal limits ${ }^{(29)}$.

In a study conducted in India with 117 children, Bhatia and his colleagues reported that only 26 of the 94 cases had macrocytosis. Mean corpuscular volume is an unreliable screening parameter for the diagnosis of macrocytic anemia, which is associated vitamin B12 deficiency ${ }^{(30)}$. In their study Balcl et al. ${ }^{\left({ }^{31}\right)}$ stated that MCV might be normal or decreased in case of mixed anemia which creates difficulties in diagnosis.

Consequently in our society, iron, vitamin B12 and folate deficiencies are very common, especially among children aged between 12 and 18 years old. Complete blood count parameters may be insufficient to predict vitamin B12 and folate deficiencies. It is not clear whether iron deficiency anemia masks macrocytosis or vitamin B12 deficiency masks microcytosis. In these conditions the clinical symptoms of vitamin B12 deficiency should be considered and blood tests should be ordered with the possibility of early diagnosis and treatment. Thus, permanent neurological complications could be prevented in childhood. School-based programs to screen and treat children for iron, vitamin B12, and folate deficiencies and anemia should be carried-out.

We have shown that anemia is a common problem in children and adolescents in our society. Despite of the limitations, our study had a large sample size. However, larger trials are needed that will take the nutritional status of the participants in consideration.

\section{Limitations}

Our study has many limitations. First of all, we have limited access to the patient information becau- 
se this is a retrospective study. Considering that the evaluation of iron profile, vitamin B12 and folate parameters may be desirable from the children who are thought to be deficient, use of a sampling method may be biased. We excluded the patients from the study with underlying chronic disease or those younger than 1 year old. However, undiagnosed acute disease could affect the parameters such as ferritin. Additionally, there was a risk for some patients with underlying yet unknown disease(s). The diagnosis of IDA was based on the ferritin level. Ferritin and iron are known to have circadian variations. The most important limitation in our study is the inability to investigate the nutritional status of children. Peripheral blood smear examination was not performed because of the retrospective design of the study. Our study did not consider the reticulocyte counts of the participants. Because of retrospective design of our study with long-term follow-up period (8 years), vitamin B12 and folate levels were measured using different instruments. Although the normal ranges were similar, the measurements should have been done using the same instruments. Use of different instruments yielded variations in results of analyses.

Etik Kurul Onayı: SBÜ. İzmir Tepecik Eğitim ve Araştırma Hastanesi Yerel Etik Kurulu onayı alınmıştır (13.7.2017/37).

Çıkar Çatışması: Tüm yazarlar bu makalenin yayımlanmasıyla ilgili olarak herhangi bir çıkar çatışması olmadığını beyan eder.

Finansal Destek: Yoktur.

Hasta Onamı: Çalışma retrospektif olduğu için hastalardan onam alınmamıştır.

Ethics Committee Approval: SBI. İzmir Tepecik Training and Research Hospital Local Ethics Committee approval was obtained (13.7.2017/37).

Conflict of Interest: All authors declare that there is no conflict of interest regarding the publication of this article.

Funding: None.

Informed Consent: As the study was retrospective, consent was not obtained from the patients.

\section{REFERENCES}

1. Short MW, Domagalski JE. Iron deficiency anemia: evaluation and management. Am Fam Physician. 2013;87(2):98104.

2. Black MM, Quigg AM, Hurley KM, Pepper MR. Iron deficiency and iron-deficiency anemia in the first two years of life: strategies to prevent loss of developmental potential. Nutr Rev. 2011;69(Suppl 1):S64-70. https://doi.org/10.1111/j.1753-4887.2011.00435.x

3. Lutter CK. Iron deficiency in young children in low-income countries and new approaches for its prevention. J Nutr. 2008;138(12):2523-8.

https://doi.org/10.3945/jn.108.095406

4. Garcia-Casal MN, Osorio C, Landaeta M, Leets I, Matus P, et al. High prevalence of folic acid and vitamin B12 deficiencies in infants, children, adolescents and pregnant women in Venezuela. Eur J Clin Nutr. 2005;59(9):1064-70.

https://doi.org/10.1038/sj.ejcn.1602212

5. Chatthanawaree W. Biomarkers of cobalamin (vitamin B12) deficiency and its application. J Nutr Health Aging. 2011;15(3):227-31. https://doi.org/10.1007/s12603-010-0280-x

6. Hannibal L, Lysne V, Bjorke-Monsen AL, Behringer S, Grunert $\mathrm{SC}$, et al. Biomarkers and Algorithms for the Diagnosis of Vitamin B12 Deficiency. Front Mol Biosci. 2016;3:27. https://doi.org/10.3389/fmolb.2016.00027

7. Brattstrom L, Wilcken DE. Homocysteine and cardiovascular disease: cause or effect? Am J Clin Nutr. 2000;72(2):315-23. https://doi.org/10.1093/ajcn/72.2.315

8. Altay C, Cetin M, Gümrük F, Irken $G$, Yetgin $S$, et al. Familial selective vitamin B12 malabsorption (Imerslund-Gräsbeck syndrome) in a pool of Turkish patients. Pediatr Hematol Oncol. 1995;12(1):19-28. https://doi.org/10.3109/08880019509029524

9. Cuevas-Nasu L, Mundo-Rosas V, Shamah-Levy T, MendezGomez Humaran I, Avila-Arcos MA, et al. Prevalence of folate and vitamin B12 deficiency in Mexican children aged 1 to 6 years in a population-based survey. Salud Publica Mex. 2012;54(2):116-24.

https://doi.org/10.1590/S0036-36342012000200007

10. Alcantara O, Kalidas M, Baltathakis I, Boldt DH. Expression of multiple genes regulating cell cycle and apoptosis in differentiating hematopoietic cells is dependent on iron. ExpHematol. 2001;29(9):1060-9. https://doi.org/10.1016/S0301-472X(01)00683-X

11. Macdougall LG, Anderson R, McNab GM, Katz J. The immune response in iron-deficient children: Impaired cellular defense mechanisms with altered humoral components. J Pediatr. 1975;86(6):833-43. https://doi.org/10.1016/S0022-3476(75)80211-3

12. Yetgin S, Altay C, Ciliv G, Laleli Y. Myeloperoxidase activity and bactericidal function of PMN in iron deficiency. Acta Haematol. 1979;61(1):10-4. https://doi.org/10.1159/000207620

13. Koc A, Kosecik M, Vural H, Erel O, Atas A, et al. The frequency and etiology of anemia among children 6-16 years of age in the southeast region of Turkey. Turk J Pediatr. 2000;42(2):91-5.

14. Ozdemir N. Iron deficiency anemia from diagnosis to treatment in children. Türk Ped Arş. 2015;50:11-9.

https://doi.org/10.5152/tpa.2015.2337

15. de Benoist B. Conclusions of a WHO Technical Consultation 
on folate and vitamin B12 deficiencies. Food Nutr Bull. 2008;29(2 Suppl):S238-44. https://doi.org/10.1177/15648265080292S129

16. Brugnara C, Oski FA, Nathan DG. Diagnostic approach to the anemic patient. Nathan and Oski's hematology of infancy and childhood, 6th edn. Saunders, Elsevier, New York 2009; 456-63.

17. Orkin SH, Nathan DG, Ginsburg D, Look AT, Fisher DE, et al. Nathan and Oski's hematology and oncology of infancy and childhood, Elsevier Health Sciences. 2015;

18. Baker RD, Greer FR. Diagnosis and prevention of iron deficiency and iron-deficiency anemia in infants and young children (0-3 years of age). Pediatrics. 2010;126(5):1040-50. https://doi.org/10.1542/peds.2010-2576

19. Bhardwaj A, Kumar D, Raina SK, Bansal P, Bhushan S, et al. Rapid Assessment for Coexistence of Vitamin B12 and Iron Deficiency Anemia among Adolescent Males and Females in Northern Himalayan State of India. Anemia. 2013; 2013:959605. https://doi.org/10.1155/2013/959605

20. Isik Balci Y, Karabulut A, Gurses D, Ethem Covut I. Prevalence and Risk Factors of Anemia among Adolescents in Denizli, Turkey. Iran J Pediatr. 2012;22(1):77-81.

21. Akbari M, Moosazadeh M, Tabrizi R, Khatibi SR, Khodadost $M$, et al. Estimation of iron deficiency anemia in Iranian children and adolescents: a systematic review and metaanalysis. Hematology. 2016; 1-9. https://doi.org/10.1080/10245332.2016.1240933

22. Kapil U, Toteja GS, Bhadoria AS. Cobalamin and folate deficiencies among children in the age group of 12-59 months in India. Biomed J. 2015;38(2):162-6. https://doi.org/10.4103/2319-4170.137768

23. Taneja S, Bhandari N, Strand TA, Sommerfelt $H$, Refsum $H$, et al. Cobalamin and folate status in infants and young children in a low-to-middle income community in India. Am J Clin
Nutr. 2007;86(5):1302-9.

https://doi.org/10.1093/ajcn/86.5.1302

24. Syed S, Addo OY, De la Cruz-Gongora V, Ashour FA, Ziegler TR, et al. Determinants of Anemia among School-Aged Children in Mexico, the United States and Colombia. Nutrients. 2016;8(7). https://doi.org/10.3390/nu8070387

25. Whitehead VM. Acquired and inherited disorders of cobalamin and folate in children. Br J Haematol. 2006;134(2):12536. https://doi.org/10.1111/j.1365-2141.2006.06133.x

26. von Schenck U, Bender-Gotze C, Koletzko B. Persistence of neurological damage induced by dietary vitamin B-12 deficiency in infancy. Arch Dis Child. 1997;77(2):137-9. https://doi.org/10.1136/adc.77.2.137

27. Chan CW, Liu SY, Kho CS, Lau KH, Liang YS, et al. Diagnostic clues to megaloblastic anaemia without macrocytosis. Int J Lab Hematol. 2007;29(3):163-71. https://doi.org/10.1111/j.1751-553X.2007.00911.x

28. Kara IH, Kandiş $H$, Bahçebaşı T, Köylü OK, Sayın $S$, et al. Check-up Polikliniğine Başvuran 50 Yaş Üzeri Bireylerin Folat, B12 Vitamini Düzeyleri ve Anemi Yönünden Değerlendirilmesi. Turkish Journal of Biochemistry. 2010;35(4):350-5.

29. Lindenbaum J, Healton EB, Savage DG, Brust JC, Garrett TJ, et al. Neuropsychiatric disorders caused by cobalamin deficiency in the absence of anemia or macrocytosis. N Engl J Med. 1988;318(26):1720-8. https://doi.org/10.1056/NEJM198806303182604

30. Bhatia P, Kulkarni JD, Pai SA. Vitamin B12 deficiency in India: mean corpuscular volume is an unreliable screening parameter. Natl Med J India. 2012;25(6):336-8.

31. Balci YI, Akpinar FO, Polat A, Uzun U, Ergin A. Evaluation of Reticulocyte Parameters in Iron Deficiency, Vitamin B12 Deficiency and Mixed Anemia. Clin Lab. 2016;62(3):343-7. https://doi.org/10.7754/Clin.Lab.2015.150616 